\title{
Matrix support and institutional support: analyzing their construction
}

Saúde Universidade de Campinas. Cidade Universitária Zeferino Vaz, Barão Geraldo. 13083 monica.psisaude@
}

\begin{abstract}
This is an analysis of the theoretical and practical construction of the methodology of Matrix Support by means of studies on Paideia Support (Institutional and Matrix Support), which is an inter-professional work of joint care in recent literature and official documents of the Unified Health System (SUS). An attempt was made to describe methodological concepts and strategies. A comparative analysis of Institutional Support and Matrix Support was also conducted using the epistemological framework of Field and Core Knowledge and Practices.

Key words Matrix support, Institutional support,

Inter-professional work, Health care networks
\end{abstract}




\section{Introduction}

The Paideia theoretical concept created by Campos ${ }^{1-3}$ arose from criticism to hegemonic management rationality and the indication of a method that favored management organization democratization, by training collective groups organized for the production of goods or services, and the incentive for subjects to participate in the organization management and its work processes. It proposes articulating knowledge and practices in the fields of collective health, clinical medicine, politics, administration and planning, psychoanalysis, institutional analysis and pedagogy for the construction of relations for work co-management.

In this sense, it preaches the reform of health organizations to seek co-management, that is, the deliberate establishment of dialogic relations, with knowledge and power sharing ${ }^{2}$. As a way of operationalizing co-management and building horizontal relations at healthcare services, the author proposes the Wheel Method that suggests replacing institutional domination and control strategies with a support relationship among the various agents and users, through the construction of communicative relations between different players involved in health production.

Campos et al. ${ }^{4}$ states that the Paideia methodology (The Wheel Method) takes place under the form of Support, and this can be used in management, with the aim of co-managing organizations and democratizing the relations in institutions and social systems (Institutional Support). It can also be used to undertake co-management in interprofessional relationships (Matrix Support) and during the clinical relationship (clinic shared between team and users) and, finally, it has been used in health education, community or public health projects.

Since it was proposed, the Paideia Method has gone deeper and was disseminated in training fields, intervention-research and expanded clinics. Notwithstanding this, when it comes to its methodological application - Institutional Support and Matrix Support - it has achieved greater recognition, as it began to be used as a guideline for the SUS - Unified Health System, and was incorporated into public health policies in Brazil ${ }^{5-9}$.

If on the one hand these measures favor dissemination of the Support concept, on the other, the goal has not necessarily been the democratization and the creation of critical subjects with greater autonomy. For this reason, we run the risk of contributing to making the concepts of "Support" and "Supporter" banal, if these do not go hand-in-hand with changes in power relationships, they will be void and not comply with the role intended by the author that proposed it. Therefore, studies on this topic are fully justified, to revisit the tradition in which the method was created, and mainly to enrich it through an investigation of its recent usage.

Thus, this article has the goal of contributing to an understanding of the Paideia Support, based on two interlocutions: one relating the Matrix Support to international production on interprofessional work and on shared care. The other is based on analogies and differences between Matrix Support and Institutional Support, based on empirical evaluations carried out in the concrete practice of this methodology and the field concepts and core of knowledge.

A literature review was done on the national production on Matrix Support, seeking its relationship with the Paideia reference and with Institutional Support. Part of the search was the work done by Onocko Campos and Furtado9, to dive into international bibliographic productions that related to the topic of Support. With this proposal, the keywords and inclusion and exclusion criteria to analyze the international bibliography were put together throughout the entire research, and not always a priori as would be done in a search for updates with the usual tools.

To follow this path, the decision was to comment on the official documents and Brazilian studies that have left a mark on the discussion of the topic of Support in the national context, besides a subsequent analysis of articles under shared care and collaborative work that are part of international literature on interprofessional work. In the same way, some concepts deemed important were redeemed to broaden understanding on Support, as is the case of the field epistemological reference and the knowledge and practices core.

\section{Interprofessional work in health: shared care, collaborative care and matrix support}

In the international bibliography we found a discussion on interprofessional work in health under the denomination of shared care and collaborative care. The methodology and the term Matrix Support were not found unless in relation to articles mentioning the Paideia Method. Nevertheless, in Brazil, the Matrix Support is used 
broadly, and has been incorporated through the approval of a strategy for Support Centers for Family Health (Núcleos de Apoio em Saúde da Família (NASF), created by Ordinance n. 154, of January $24,2008^{10}$. This policy foresees resources destined specifically to hiring professionals for the Family Health teams that use the work methodology based on the Matrix Support structural arrangement ${ }^{4}$.

Matrix Support is a work methodology, a series of concepts on "how to do" the interprofessional work, in teams as well as in health care networks (exercise the support function), in co-management, in a shared way ${ }^{11}$. The Matrix Support methodology was used initially in the first years of the 1990's, at the SUS/Campinas. It became a strategy to think about the relation between primary care network and mental health center teams; it was later experimented in hospitals, AIDS Reference Centers, rehabilitation and others $^{12-14}$

Although Matrix Support is a way or organizing interprofessional work, it can also be understood as an organizational arrangement, or a structural place (position), based on which work is done, eminently with a support function. This is what happened with the creation of the Support Centers for Family Health (NASP).

Three guidelines are set forth, on both of these dimensions: to take the logic of support and of co-management to interprofessional relationships; to deal with social, sanitary and pedagogic processes based on the reference of interdisciplinarity; and, to build multiprofessional teams with co-responsibilities in health care ${ }^{4}$.

This is therefore a device and methodology to overcome the logic of referrals, which fragments care and compromises clinical responsibility during interdisciplinary care (whenever more than one professional is involved with care). The Matrix Support methodology fosters activation of communication spaces and joint deliberations, for knowledge sharing and organization of health care network flows, breaking with red tape present in the reference and contra-reference modality ${ }^{15,16}$.

In this matrix arrangement, professionals from specialized areas that do not participate integrally in the day-to-day Reference Teams offer specialized backing and technical-pedagogical support to these teams. This way, the intention is to dynamically and interactively warrant an exchange of knowledge that will contribute to expanding the possibilities of setting up therapeutic projects, of carrying out an expanded clinic and favor the integration of dialogue between the different specialties or healthcare professions. This will facilitate exploring the diverse fields and centers of competence that are necessary for each case $^{4,15,16}$.

Gonçalves $^{17}$ draws attention to the fact that the proposal of setting up that knowledge exchange and shared care between different professionals, with the intention of expanding possibilities and qualifying care, particularly among the Primary Care teams and specialists, has been used in the international context, which includes the United Kingdom, Ireland, Australia, Canada and Spain. In these countries, it takes on different nomenclatures, such as shared care and collaborative care, and above all refers to care in chronic diseases, more specifically, in the treatment of diabetes and in mental health.

In 1994, a collaborative care program was created in Canada, including specialists in mental health and nutrition in Ontario. This program was expanded to "middle-Canada", beginning in $1996^{18}$. Then, in 1997, a College was created, with the functions of a regulatory committee, and the aim of facilitating collaboration between psychiatrists and physicians in Primary Care throughout the Canadian territory ${ }^{19}$.

Vingilis et al. ${ }^{18}$ point out that professionals involved in collaborative care refer to the perception of a reciprocal development of skills, with shared learning, and that this proposal for work has proven to be successful in improving access, communication and collaboration among physicians and working conditions, as it offers family doctors tools to deal with problems of greater complexity.

In Portugal, there is still no systematic program for shared care, however, the Primary Care practices of professionals in psychology and in nutrition already begin to be based on that relationship of dialogue and collaboration between multidisciplinary teams, especially in Intensive Care Units in the Community, where they contribute to the planning and implementation of activities in the territory. In the Family Health Units, although what prevails is individual care per specialty, professionals have organized themselves to discuss cases in an interdisciplinary way. In any fashion, it is possible to foresee, albeit at an embryonic stage, initiatives in shared care, although this was not underscored in Gonçalves work $^{17,20,21}$.

In Spain, García-Talavera Espín et al. ${ }^{22}$ point to Murcia's example, where in 2007 an interdisciplinary unit in diabetes care was created, coordi- 
nated by endocrinology and made up of diabetes educator nurses, dietitians, surgeon, nurses specializing in the diabetic foot, ophthalmologist, emergency physician and rehabilitation physician, besides 10 general practitioners and 10 primary care nurses, who, furthermore coordinate the rest of the health teams in the Primary Care Units of their region and specialized services for diabetic patients at the Reina Sofia Hospital, in Murcia. According to the authors, this interactive work among the Diabetes Care Units and Primary Care services has contributed to decreasing the number of emergencies and hospitalizations, besides enhancing interdisciplinary communication.

In the United Kingdom, Barbara Starfield ${ }^{23}$ explains that the ever-growing complexity of challenges in medical practice has demanded the construction of new organization models, considering that Primary Care, in isolation, no longer suffices to service the challenges imposed by chronic diseases and comorbidities. She advocates for the different interfaces that are possible, based on the relationship between Primary Care and Specialties, since patients have expressed they are more satisfied with care and shared care, leading to a reduction in the number of tests and procedures. Additionally, the author attributes greater resolution capacity in Primary Care, in the United Kingdom, to the possibility of having communication between general practitioners and other specialists.

In Ireland, although there is an ongoing discussion on the issue referring to chronic diseases, the authors point to the fact that, faced with the different results found in the literature review, they cannot state in a trustworthy way that shared care offers significant benefits, except for the improvement in medication prescription. They therefore believe there is no sufficient evidence to support the expansion of shared care, while supplementary studies are not carried out, with methodological rigor ${ }^{24}$.

In Australia however, the interest for shared care proposals in the country dates back to 2008 . Kelly et al..$^{25}$ point out that the Committee on sentinel events in mental health, from the New South Wales government, declared, in 2008, there were insufficient standards to guide shared care practices in mental health, and that the Health Department in 2010 commissioned a study to review evidence on shared care models used in mental health.

In these contexts, shared care/collaborative care are defined by the joint participation of Primary Care professionals and specialists in the planning of therapeutic projects, mediated by organizational arrangements which, as a rule, also seek to encompass some of the following components: i) introduction on the role of coordination in Primary Care cases, with systematic and structured interventions from primary care physicians; ii) introduction of mechanisms for connection between professionals; iii) development of strategies to collect and share information on patients progress ${ }^{24,26}$.

Bower et al. ${ }^{26}$ comment that interventions in shared care vary a great deal, in content and intensity, besides the fact there are scarce studies on the topic. For that reason, it is not clear which would be the indispensable aspects to put the proposal in place.

The variety of arrangements and formats that shared care takes on can be understood beyond being a problem, and as a characteristic of flexibility that is necessary for it to adapt to several different scenarios, according to the uniqueness of each of them. On the other hand, studies converge in highlighting that many variables compete so that shared care can be implemented, and that an analysis of these components could help strengthen the proposal.

Starfield $^{23}$, for example, draws attention to the need to clarify the new role of specialists in this new arrangement. According to the author, insertion of these professionals takes place under different forms: brief consultations or visits, timely interventions in which the Primary Care teams do not have the equipment nor the necessary knowledge; acting in continued care through consultancy to the Primary Care teams on emerging issues in cases; or they may evolve when the Primary Care team totally transfer the care of certain patients to them.

Nevertheless, she defends that a more appropriate role for specialists, as part of this proposal of interdisciplinary relations, would be that of consultants, without excluding the possibility of periodic visits to Primary Care services to visit groups of patients. She actually sees in these visits a significant space for knowledge exchange and mutual learning ${ }^{23}$.

In the meta-analysis carried out by Foy et al. ${ }^{27}$ on shared care and interprofessional communication, a main factor associated to the effectiveness of this model also came up, regardless of the coefficient of integration of the health system. For them, it would also be important to build organizational coordination for teams to work this way. Their role would be to deal with the embarrassment relating to the lack of time in the 
agenda and the difficulties of holding meetings to guarantee the potential for interactive communication among professionals.

This way, the evaluation done by Vingilis et al. ${ }^{18}$ on the processes of a collaborative care program in Canada points to communication, mediated by an "open door policy", as being an important point, besides daily contact with other professionals, and the joint construction of therapeutic projects.

Kelly et al..$^{25}$, present a list of elements which could contribute to putting in place shared care and call them "the main ingredients". They are: i) systematic approximation and involvement of generalist services with specialized ones, through the construction of a common goal to enhance care; ii) the drafting of a model consistent with the needs of the target population; iii) an agreement to define clinical monitoring model for patients, contemplating the possibility of meeting to review the cases, whenever necessary; iv) attention to issues referring to screening and hiring of personnel, associated to the guarantee of clinical supervision spaces to support the development of skills and to maintain the assistance model; v) strengthening the clinic management fora.

Kates and Craven ${ }^{19}$ remind us that managers have begun to accept the principles of shared care but that, if we wish to move forwards, it is necessary to do more. Firstly, it would be necessary to invest massively in training healthcare professionals who will be working according to this logic, which includes changes in undergraduate and residency syllabus. Secondly, it would be necessary to guarantee that the new shared care projects be based on evidence, as much as possible. And finally, they recommend the construction of a single group of indicators to evaluate projects, set up shared jargon and to build and agenda to research the matter.

Despite the validity of the recommendations made by these shared care studies, to qualify interprofessional work, it is important to mention that the Brazilian proposal for Matrix Support manages to bring together recommendations from programs from other countries, presenting and adding new outlooks and strategies that were absent in the description of international studies. The Support Matrix methodology recommends: a) personalizing interprofessional relationships, recovering that old tradition when exchanging shifts of conveying to the new team information on the case, live and face- to-face. The search is for forms for personal contact, and not only the flow of red tape of cases through intercon- sultation requests or referral and contra-referral cards; b) the Support process begins with setting up the contract, in terms of the organization of this interprofessional relationship, taking into account Support guidelines, but always with freedom to adjust them to the context. An important element of this contract is to present the risk criteria to organize sharing; c) a clear definition of responsibilities per case can be shared through joint care, or simultaneous care, the coordination of the therapeutic project can vary according to the case and the phase of the case; d) use of co-management forms and the wheel method (Support) during interprofessional practice, such as: support is created among professionals with different knowledge cores, aimed to expand management, and the differences should be explained as offers, that is, as distinctive visions, but ones that will always be subject to criticism and reconstruction through a collective debate; e) Matrix Support is also a form of permanent education and reconstruction of oneself, as it creates collective spaces for thought on practices and crystallized certainties.

Support is a Praxis ${ }^{28}$. Praxis and not only a technology or a tool. It is a dialectic method, a constellation of concepts that can be united in different ways, according to the goal and specificity of each case.

Matrix Support was built through the combined influence of an epistemological and political reference and a heuristic centered in case studies. It was based on traditions of theoretical and political bets arising from the Public and Universal Health Systems and, in particular, the SUS. Specifically, it was based on the broadened concept of health production, and on the bet of setting up institutions and health practices with a democratic nature. It was also set up as a methodological application of the Paideia Method, set forth by Campos ${ }^{1,2}$ which gives it rather unique features when compared to shared care projects.

A distinctive characteristic of Matrix Support is its commitment with the construction of institutions and democratic working relations, which means that it also has the goal of collaborating towards power distribution among the different players involved. In other words, it brings to the fore an element that tends to be marginalized in clinical discussions: politics ${ }^{2,4}$.

To explicitly take on the undertaking to deal with politics in the management and practice of health relates to the understanding that, in fact, politics, management, clinics and the promotion of health are inseparable, indissoluble elements 
concretely. The interdependent consideration of these dimensions highlights the new role of both the workers and the users of these services.

In this sense, Matrix Support also sets itself aside for presupposing co-management and the shared construction of care, which implies having organizations that will ease the relationships, the communication and dialogue among healthcare professionals, and, above all, between the latter and users, so they can actively participate in drafting up therapeutic projects.

The Matrix Support methodology uses the concepts of the Frankfurt School theory and methodology, which averts the rigidity of modern Science, since it thinks of theory and method in a dialectic way ${ }^{29}$. There is no ideal method for all and any situation. The method should be built keeping in mind its relationship with the thematic area of application, that is to say, with the object, with the question or with the working hypothesis. For example, the map of conceptual cores that make up the Matrix Support, presented above, was imagined in view of the interprofessional work in teams and in healthcare networks. Contrary to the traditional understanding in Marxism, the dialectic here is understood as a process in which the interactions and synthesis between elements produce not only synergic but also contradictory effects, in which new social contracts and new contradictions are created ${ }^{4}$.

It is precisely based on this stance of recognizing the conflict and the contradiction interwoven with the movements of composition and negotiation that the Paideia methodology tries to integrate in society and individuals - players that intervene and suffer the consequences of living in society and relating ones to the others ${ }^{2}$.

Thus, it is necessary to work based on a recognition of the conflict and mutual transformation inherent to the dialectic process that guides personal and institutional relations, perceive politics as an element that is present in clinical work and in interprofessional relations, and mainly; to set aside the place of the user as a subject that actively participates in the construction of care and health services.

Matrix Support can be better put to work if it bases itself on a logic of separation into territories, in which each group of specialists serves as reference for a specific area, making it possible to build connections among professionals, despite their sporadic participation. This logic corresponds to the proposal contained in the Dawson Report $(1920)^{30}$ and has been used in the United Kingdom ${ }^{23}$.

\section{Matrix support and institutional support: discussion based on field concepts and the core of knowledge}

This discussion makes sense if we think of the results of various evaluations of the practice of Matrix Support and Institutional Support, mainly in the structural arrangement dimension, that is, when there are two characters more than the usual on the scene: the Institutional Supporter and the Matrix Supporter.

This topic gained importance beginning in 2003, when the Ministry of Health began a process to formulate and implement Institutional Support in states and municipalities. Initially, it focused on two perspectives: on support to a decentralized management for the SUS - coordinated by the Department for Support to Decentralization (DAD) of the Executive Secretary - and on support to changes in management and care models in health systems and services - coordinated by the National Humanization Policy (Humaniza/SUS). Another important movement took place in 2011, when the Ministry of Health implemented Institutional Support, seeking to articulate the different secretariats and departments, called Integrated Institutional Support, coordinated by the Managing Center for Integrated Support (made up of all of the Ministry of Health Secretariats and coordinated by the Executive Secretariat). Immediately thereafter, some State Health Deoartments also created these institutional support centers to make a list of the municipal secretariats and services, with a highlight to the Primary Care Superintendence in Rio de Janeiro, the Primary Care Board from Bahia and the State Family Health Foundation from Bahia ${ }^{5,6,8}$.

Additionally, this discussion was brought up at several moments during the specialization course "Support in Health", offered by the Primary Care Department (DAB) in partnership with the State University of Campinas (UNICAMP), with the target audience being professionals working with Institutional Support. The course, held between August 2012 and September 2013, convened professionals from the three federal spheres: municipalities, state and the ministry of health, coming from different Brazilian states. Along the way, the confusion between what Matrix Support meant and Institutional Support became patent, and a discussion was held to distinguish, perhaps merely for pedagogic purposes, how to organize the practice of these professionals and bring back the meaning of being a 'Supporter". 
To share the discussion held in that space and others seems interesting to contribute to the construction of the identity of professionals of Matrix Support and Institutional Support, without denying the overlays and complementarity that both present, and mainly without hampering the best on expanding the clinic. For this, the redemption of field concepts and the core proves to be useful as a strategy to analyze work in the Matrix Support and Institutional Support.

Between 1994 and 1997, during a project on training and medical specialization in Brazil, funded by the Federal Council for Medicine (CFM) and the Brazilian Medical Association (AMB) the concepts of field and center or core were created. They are born from the recognition of an increase in theoretical production regarding the interdisciplinarity and the existence of a paradox in the field of knowledge: of, on the one hand, the paranoid isolation of professions, and on the other, the schizophrenic merger between knowledge, that oftentimes culminates in an exemption of responsibility in health care ${ }^{2}$.

In this sense, Campos ${ }^{31,32}$ explains that the concepts of core and field conform to criticism not only of corporatism and disciplinary closing, but also to the post-modern trend of diluting knowledge to such a point that it makes it unviable to build a professional identity for subjects. Therefore, it makes it difficult to build curricula and roles for each profession in day-to-day work. Which meant to say they set up an initiative to tackle the dilemma between corporate bureaucratization and the interdisciplinary dilution of professions and specialties.

The core represents the more structured face of knowledge and of the roles that circumscribe disciplines, and helps to build the identity and specificity of professions. It is made up of a set of knowledge and specific attributions (tasks) and characteristics of each profession and therefore, collaborates to materializing the commitment of this with the production of usage values. The proposal is to call the core the difference between the roles and knowledge in the several professions ${ }^{2,16,31}$.

The field indicates a set of knowledge and tools of that a profession should take ownership of to achieve efficiency and efficacy in specific contexts. These characteristics grant it a situational conception and a mutant configuration. The field represents the possibility of crystallized identity built by the core, which is able to open itself to the world of inderdisciplinarity and interprofessionalism ${ }^{2,16}$.
Nevertheless, it is worth underlining that despite the didactic differentiation that is set forth, the relation between these two concepts is not one of polarity or antagonism. The core indicates an agglutination and a specific concentration of knowledge and practices, but in a certain way points to a radical break with the field dynamic as well. Much the contrary, in the author's concept ${ }^{2}$ the core as well as the field would be mutant and influencing one another, without stringent limits between one and the other.

Despite the fact these concepts were created to explain training in the medical area, their application extends beyond, and they have been used to explain collective health practices, besides helping to characterize actions of the Matrix Support ${ }^{16,33}$.

Much like the field and core concepts contribute to an understanding of collective health actions and also for the work of Matrix Support, as they are the critical reference to explain the relationship between Matrix Support and Institutional Support when they take on the character of a work position or organizational arrangement.

Institutional Support is characterized by a methodology that seeks to set forth traditional management mechanisms by doing this through co-management. It presupposes an interactive stance, analytical as well as operational, which would supplement and transform the way of performing managerial functions, such as coordination, planning and direction - Support to make feasible the government and management of the co-management model ${ }^{4}$.

The Matrix Support, as presented previously, takes places in the day-to-day professional practices and in a shared way with users. It refers to support in the context of an expanded clinic and of promotion, and begins from a springboard of purported knowledge while, at the same time, of professional power. It intends to modify work relationships, and has as its guide co-management and support on interprofessional relations; interdisciplinarity with knowledge sharing and teamwork with responsibility over the population ${ }^{4}$.

In this sense, and by using the field and core concepts in the habitual way, what can be identified is that Matrix Support is made up of professionals with different cores of knowledge, dialoguing and exchanging knowledge among themselves to build a field that is appropriate for a given and unique therapeutic project, in so far as each profession seeks support in the other areas to fulfill the tasks. Nonetheless, another possibility can be foreseen to approach the relational 
object of Matrix Support, making it possible to differentiate it, without however distancing it from Institutional Support.

It could be said that the core of Matrix Support refers to the clinic and that of Institutional Support refers to management. This does not exempt the clinic and collective health from the responsibility of Institutional Support, nor does it eliminate the politics and management of Matrix Support. A psychologist who works with Matrix Support has as the core psychology and subjective relationships, contributing to broadening the approach, particularly, in the psychosocial dimension, of teams with other trainings. For the psychologist to fulfill this goal, he/she will necessarily have to know about the discussion of the care model, management and health policies; albeit such topics are part of his/her field of tasks, but not of the core, as he/she does not work with the different management function. If this psychologist were in a position in Institutional Support, he/she would also continue with psychology as the core, as this is the area of his/her graduation course, but he/she would also take responsibility for the management and policy core.

In this fashion, it is indispensable that Matrix Support contribute incisively to the clinic and Institutional Support in management. Evidently, the scope of these professionals should not be limited to the core of Support they are associated to, but they cannot ignore that this would be their role par excellence.

In terms of the field of Support functions, and whether the professional is in a management position or in care teams, it can be said that it is composed of core issues in collective health, such as teamwork, the management model, the health care model, group relations, planning, the ordainment of the assistance network, among others ${ }^{2}$.

Many a times confusion arises when the Institutional Supporter discusses and intervenes in topics that refer to the clinic, and as a counterpart, the Matrix Supporter also contributes to operating changes in management, aimed at making it more democratic. All of this should be understood as legitimate and necessary, as they are about praxis in the field of knowledge, which does not compromise or undo the respective cores that ensure the specificity to Matrix and Institutional Support. They remain whole in their role of organizing professional identity.

The use of field and core concepts in the context of Institutional Support and Matrix Support contribute, therefore, not only to the differentiation between these two categories, but mainly provides instruments or the construction of identity and the role of workers who perform these functions and make it possible to expand knowledge on Support.

The field and core concepts spring from the knowledge paradox of the difficulty of operating, in practice, between trans-discipline and discipline, between unique knowledge on a case and integral knowledge, between taking over management (the tasks of some) and participating in management (the right of all). We conclude that the functions of Institutional Support and Matrix Support are different and supplementary, and can contribute to the construction of new relationships at work, and to consolidate the Unified Health System.

\section{Final Considerations}

The brief discussion presented does not deplete the theme of co-management, of Support, of institutional democratization and praxis in health, but contemplates the objective of casting light in the unfolding in the use of the concept and the practices incorporated into public health policies in Brazil. Similarly, it intends to motivate new research and debates that can contribute to not making banal the "being Supporter" and to redeem the democratic radicalness upon affiliating oneself to the Paideia Method (the Wheel Method).

Similarly, the discussion undertaken herein does not have the aim of polarizing Matrix Support and Institutional Support, and neither hampering its possibilities of transformation to adjust to local reality. Furthermore, it intends to inform that yes, there does exist some uniqueness and that this can be used to situate the "Supporter" in his/her job, so they will not feel lost or displaced from the conceptual and historic construction. 


\section{Collaborations}

MM Oliveira e GWS Campos participated equally in all stages of preparation of the article.

\section{Acknowledgments}

We thank all the professionals who work with Support and contributed, with their effort and dedication, to the progress on this subject.

\section{References}

1. Campos GWS. Equipes de referência e apoio especializado matricial: um ensaio sobre a reorganização do trabalho em saúde. Cien Saude Colet 1999; 4(2):393-403.

2. Campos GWS. Um método para análise e co-gestão de coletivos. São Paulo: Hucitec; 2000.

3. Campos GWS. Saúde Paidéia. São Paulo: Hucitec; 2003.

4. Campos GWS, Cunha GT, Figueiredo MD. Práxis e formação Paideia: apoio e cogestão em saúde. São Paulo: Hucitec; 2013.

5. Brasil. Ministério da Saúde (MS). Secretaria de Atenção à Saúde. Núcleo Técnico da Política Nacional de Humanização. HumanizaSUS: A Clínica Ampliada. $4^{a}$ ed. Brasília: Editora do Ministério da Saúde; 2004.

6. Brasil. Ministério da Saúde (MS). Secretaria Executiva. Departamento de Apoio à Descentralização. Apoio integrado à gestão descentralizada do SUS: estratégia para a qualificação da gestão descentralizada. Brasília: Editora do Ministério da Saúde; 2004.

7. Brasil. Ministério da Saúde (MS). Diretrizes do NASF Núcleo de Apoio a Saúde da Família. Brasília: Editora do Ministério da Saúde; 2009.

8. Brasil. Ministério da Saúde (MS). Secretaria-Executiva. Diretrizes do Apoio Integrado para a qualificação da gestão e da atenção no SUS. Brasília: MS; 2011.

9. Onocko Campos RT, Furtado JP. Narrativas: utilização na pesquisa qualitativa em saúde. Rev Saude Publica 2008; 42(6):1090-1096.

10. Brasil. Ministério da Saúde (MS). Portaria no 154, de 24 de janeiro de 2008. Cria os Núcleos de Apoio à Saúde da Família - NASF. Diário Oficial da União 2008; 25 jan.

11. Campos GWS. Equipes de Referência e apoio especializado matricial: um ensaio sobre a reorganização do trabalho em saúde. Cien Saude Colet 1999; 4(2):393-403.

12. Domitti ACP. Um possível diálogo com a teoria a partir das práticas de Apoio Especializado Matricial na Atenção Básica de Saúde [tese]. Campinas: Universidade Estadual de Campinas; 2006.

13. Campinas. Colegiado de Gestão da Saúde. As Diretrizes da Secretaria Municipal de Saúde - Gestão 2001 - 2004. Projeto Paideia de Saúde da Família. Campinas: Secretaria Municipal de Saúde; 2001.

14. Campinas. Programa Paidéia - Saúde da Família: 20012004: Campinas. Campinas: Secretaria Municipal de Saúde; 2003.

15. Campos GWS, Domitti AC. Apoio Matricial e equipe de referência: uma metodologia para gestão do trabalho interdisciplinar em saúde. Cad Saude Publica 2007; 23(2):399-407.

16. Cunha GT, Campos GWS. Apoio Matricial e Atenção Primária em Saúde. Saúde e Sociedade 2011; 20(4):961970.

17. Gonçalves DA. Prevalência de transtornos mentais na Estratégia Saúde da Família e avaliação de um modelo de capacitação em Saúde Mental [tese]. São Paulo: Universidade Federal de São Paulo; 2012.

18. Vingilis E, Paquete-Warren J, Kates N, Crustolo A, Greenslade J, Newman S. Descriptive and process evaluation of a shared primary care program. The Internet Journal of Alleid Health Sciences and Practice 2007; 5(4). 
19. Kates N, Craven M. Collaborative Working Group of the College of Family Physicians of Canada, Canadian Psychiatric Association. Shared mental health care. Update from the Collaborative Working Group of the College of Family Physicians of Canada and the Canadian Psychiatric Association. Can Fam Physician 2002; 48:936.

20. Pisco L. Reforma da Atenção Primária em Portugal em duplo movimento: unidades assistenciais autónomas de saúde familiar e gestão em agrupamentos de Centros de Saúde. Cien Saude Colet 2011; 16(6):2841-2852.

21. Trindade I, Teixeira JAC. Psicologia nos cuidados de saúde primários. Lisboa: Climepsi; 2010.

22. García-Talavera Espín NV, López-Ruiz A, Nuñez Sánchez MÁ, Meoro Avilés A, Sánchez Cañizares C, Romero López-Reinoso H, López Olivar MD, Lapaz Jorge MÁ, Guirao Sastre JM, San Eustaquio Tudanca F, Soriano Palao J; Collaborative Group of the Diabetes Unit of the Reina Sofía University Hospital Murcia, Spain. How to reduce avoidable admissions due to acute diabetes complications?: interrelation between primary and specialized attention in a diabetes unit. Nutr Hosp 2012; 27(6):2079-2088.

23. Starfield B. William Pickles Lecture. Primary and specialty care interfaces: the imperative of disease continuity. Br J Gen Pract 2003; 53(494):723-729.

24. Smith SM, Allwright S, O'Dowd T. Effectiveness of shared care across the interface between primary and specialty care in chronic disease management. Cochrane Database Syst Rev 2007; (3):CD004910.

25. Kelly BJ, Perkins DA, Fuller JD, Parker SM. Shared care in mental illness: A rapid review to inform implementation. Int J Ment Health Syst. 2011; 5:31.

26. Bower P, Gilbody S, Richards D, Fletcher J, Sutton A. Collaborative care for depression in primary care. Making sense of a complex intervention: systematic review and meta-regression. Br J Psychiatry 2006; 189:484-493.

27. Foy R, Hempel S, Rubenstein L, Suttorp M, Seelig M, Shanman R, Shekelle PG. Meta-analysis: effect of interactive communication between collaborating primary care physicians and specialists. Ann Intern Med 2010; 152(4):247-258.
28. Campos GWS. A mediação entre conhecimento e práticas sociais: a racionalidade da tecnologia leve, da práxis e da arte. Cien Saude Colet 2011; 16(7):3033-3040.

29. Jameson F. O marxismo tardio ou a persistência da dialética. São Paulo: Editora da Unesp, Boitempo Editorial; 1997.

30. Organização Pan-Americana da Saúde (OPAS). Informe Dawson sobre el futuro de los servicios médicos $y$ afines - 1920. Washington: OPAS; 1964. Publicacíon Científica, n. 93.

31. Campos GWS. Campo e núcleo de conhecimentos e de responsabilidade. In: Campos GWS, organizador. Memórias de um médico sanitarista que virou professor enquanto escrevia sobre. São Paulo: Hucitec; 2007. p. 117-118.

32. Campos GWS. Saúde pública e saúde coletiva: campo e núcleo de saberes e práticas. Cien Saude Colet 2000; 5(2):219-230.

33. Campos GWS. Clínica e Saúde Coletiva compartilhadas: teoria Paideia e reformulação ampliada do trabalho em saúde. In: Campos GWS, organizador. Tratado de Saúde Coletiva. 2a ed. São Paulo: Hucitec; 2012. p. $19-41$.

Article submitted 29/10/2013

Approved em 18/03/2014

Final version submitted 24/04/2014 